\title{
Four-Page Fabric Books Help Students Telling Stories
}

\author{
Zaharilah Abdul Kadir ${ }^{*}$, Nur Farhana Mustahidin², Nur Farahin Mustahidin ${ }^{3}$ \\ ${ }^{1}$ Institut Pendidikan Guru Kampus Raja Melewar Seremban Negeri Sembilan, Malaysia \\ ${ }^{2}$ Unit Teknologi Pembinaan Bangunan Jabatan Kejuruteraan dan Kemahiran, Kolej Komuniti Jelebu, \\ Negeri Sembilan, Malaysia \\ ${ }^{3}$ Kolej Profesional Mara, Melaka, Malaysia \\ *Corresponding author. Email: zaharilahiprm@gmail.com.
}

\begin{abstract}
Educators and parents often look for teaching and learning materials for students based on a number of features, namely, materials that are easy to find, affordable and teacher-parent-friendly. Researchers have created a four-page fabric book as a resource to help teachers and parents engage in story-telling activities during class. The purpose of storytelling activities is to increase vocabulary, improve communication ability and student confidence. Four-page fabric books have storylines through characters, objects and situations created using a variety of fabrics. This qualitative study uses observation and interview methods to obtain data. The findings show that teachers can produce four-page storybooks and that teachers are confident that activities can be carried out with students. The formulation of appropriate aids can help teachers diversify the material in their student storytelling activities.
\end{abstract}

\section{Keywords: Fabric books; storytelling; vocabulary; communication}

\section{INTRODUCTION}

The Primary Education Curriculum (KSSR) Special Education (Learning Problems) is built in accordance with the National Education Philosophy, based on the principles of integrated approach, holistic individual development, equal educational opportunities and quality education for all students and lifelong education. KSSR Special Education (Learning Problems) 3M Foundation is holistic, as envisaged in the Malaysian Education Development Plan (PPPM) 2013-2025. Planned PdP strategies should emphasize student-centered learning and activity-based PdP. Students are actively involved in the PdP that integrates knowledge acquisition, mastery of skills and the application of attitudes and values. The planning, educational goals and strategies of the PdP need to be documented in the Individual Education Plan (RPI).

To enhance the learning interest and enjoyment, teachers can incorporate teaching approaches such as inquiry-based learning, constructivism, contextual learning, mastery learning, task analysis, learning through play, themed teaching, experiential learning, collaborative and multi-sensory approaches.

Storytelling is an activity that captures students' attention, because through storytelling they can understand something more deeply and indirectly enable students' imagination to think more creatively. Through storytelling techniques, students can learn in a happy and cheerful atmosphere. Usually when a student learns in a happy environment it is easier to understand and remember what they are learning. Humans tend to remember things that bring them joy and happiness rather than things that don't affect them.

Storytelling is one of the most effective approaches used to build language proficiency because storytelling is something that catches the attention and attention of students. During storytelling activities students can expand their vocabulary and grammar.

The objective of this study is to see how a four-page fabric book helps students tell stories. The research question is how a four-page fabric textbook can help students tell.

\section{METHOD}

Storytelling techniques are a form of learning technique that can stimulate learning among students. Stories containing themes and plot along with the use of good language style, background, situation, and point of view are good storytelling.

Thus, storytelling techniques may help improve student vocabulary, improve student communication skills and indirectly make students more confident in performing various activities at school. Storytelling involves the two-way relationship between teacher and student, and between student and student. This technique can also be manipulated according to the suitability and ability of the teacher. Students can experience their own story situations through the use of teacher-tailored teaching aids while storytelling techniques are used in the classroom. In addition, the use of pictures or storytelling is said to train students to think (Shahabuddin \& Rohizani 2003). 
The study was qualitatively conducted and data were collected through observation and interview. The target is two special education students with learning problems studying in the first grade at a school in Seremban.

Researchers build their own teaching aids that are innovative in the form of fabrics. Steps to building a four-page storybook:

1. Step 1: Special education (learning problem) teachers take in-service courses at IPG to produce a four-page storybook.
2. Step 2: Special education (learning problem) teachers produce four-page storybooks with students.

3. Step 3: Students can create their own stories based on the four-page storybook they produce.

4. Step 4: Students are guided by the teacher using words that are not commonly used throughout the day to create the story.

The PDCA study model was applied in the study as a guide in conducting the study. Plan (P), Do (D), Check (C), Action(A)

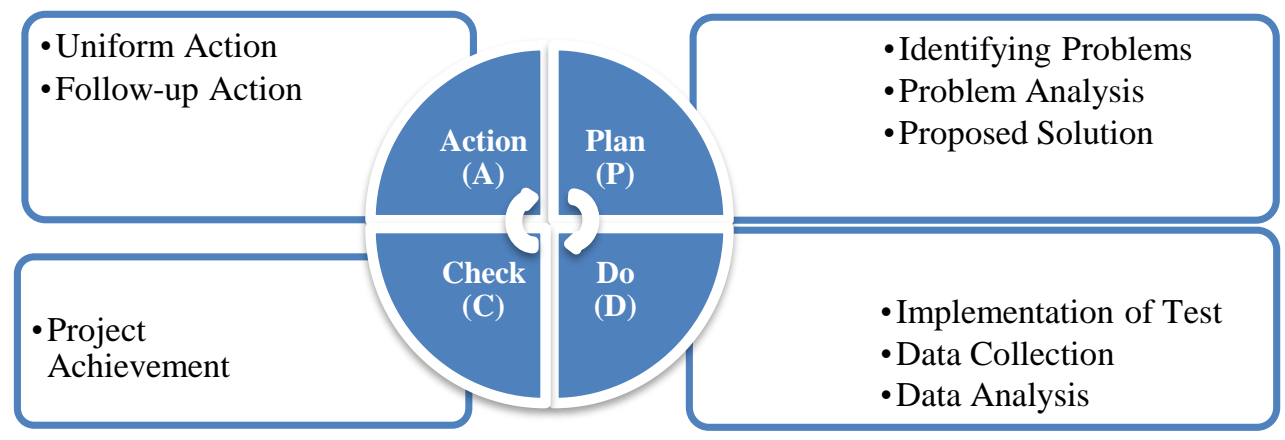

Figure 1: Four-Page Storybook Activity Implementation Model Table 1: Description of PDCA Model

\begin{tabular}{|c|c|c|}
\hline PDCA & Step & Action \\
\hline \multirow[t]{3}{*}{$\begin{array}{l}\text { Plan } \\
\text { (P) }\end{array}$} & Identifying Problems & $\begin{array}{l}\text { Teaching and learning lack the ability of students to tell stories using } \\
\text { story books. }\end{array}$ \\
\hline & Problem Analysis & $\begin{array}{l}\text { - } \text { Safety factor } \\
\text { - Lots of equipment } \\
\text { - Long preparation time }\end{array}$ \\
\hline & Proposed Solution & The activity of producing a four-page storybook. \\
\hline \multirow[t]{3}{*}{$\begin{array}{l}\text { Do } \\
\text { (D) }\end{array}$} & Implementation of Test & $\begin{array}{l}\text { Special education (learning problem) teachers produce a four-page } \\
\text { storybook with special education students with learning problems. }\end{array}$ \\
\hline & Data Collection & Through observation and interviews. \\
\hline & Data Analysis & $\begin{array}{l}\text { - } \text { Minimum monitoring during activity. } \\
\text { - Student engagement is more active. } \\
\text { - Students show interest and prepare a four-page book until } \\
\text { - } \quad \text { Better time management of activities. } \\
\text { - Safety factor using controlled scissors. }\end{array}$ \\
\hline $\begin{array}{l}\text { Check } \\
\text { (C) }\end{array}$ & Project Achievement & $\begin{array}{l}\text { - The process of creating a four-page storybook is easier, faster, and } \\
\text { safer. } \\
\text { - Special education students with learning problems succeeded in } \\
\text { producing a four-page storybook from start to finish. } \\
\text { - Environmental sustainability is safeguarded because there is no } \\
\text { fabric removal. } \\
\text { The quality of the four-page storybook is very similar to the } \\
\text { existing product on the market using fabric, paper and low } \\
\text { manufacturing costs. }\end{array}$ \\
\hline $\begin{array}{l}\text { Action } \\
\text { (A) }\end{array}$ & $\begin{array}{l}\text { Uniform Action and Follow-up } \\
\text { Action }\end{array}$ & $\begin{array}{l}\text { - Lecturers spread the activity of producing four-page storybooks } \\
\text { through courses in service to special education (learning problem) } \\
\text { teachers. }\end{array}$ \\
\hline
\end{tabular}




\section{RESULTS AND DISCUSSIONS}

Guided by the PDCA Model, in the Plan (P), the researcher made a preliminary assessment, the researcher found that during teaching and learning (PdP), the teacher lacked the ability of students to produce their own material in four-page storybook activities. Problem analysis also shows several factors that cause fine motor activity of producing story books less applicable, including student safety factors when using various equipment such as scissors, which requires supervision and students cannot be allowed to use sharp tools by themselves. The use of large amounts of equipment in activity and long preparation time to carry out activities among the contributors to building a four-page storybook is not popular for implementation in the PdP special education learning problem.

Next Do (D), testing with special education students with learning problems. Through observation and interviews, the researchers found minimal monitoring during the activity because the equipment was poorly used. More active student's involvement, students show interest and get work done and better time management of activities. While the security factor is very controlled because of the minimal equipment used.

In the next PDCA series Check (C), the process of producing a four-page storybook is easier, faster, and safer. Special education students with learning problems succeeded in producing a textbook from start to finish with a neat and usable product. Environmental sustainability is also protected because there is no fabric removal. The quality of the storybook is similar to the existing products on the market using fabric, rugged fabric and low manufacturing costs.

Action (A) is the final act of the study, the standardization and subsequent action taken. The researchers interpreted the statement of Special Education Learning Problems curriculum and adapt it to the strategy drills using fine motor activities, in the statement of curriculum, materials are applied in the PdP to help students master the concepts and knowledge and to increase the use of vocabulary in Malay language subject. PdP activities need to be varied and balanced to make student learning more effective and meaningful such as: indoor and outdoor activities; active and passive activities; individual, group and class activities; as well as student-based activities and teacher-planned activities.

The study consisted of two special education students with learning problems at a school in Negeri Sembilan. The researcher alongside a teacher, who is also a research fellow, has undertaken the activity of producing a four-page book with special education students on learning problems, and the findings of this study answer the research question, which shows that students can produce their own four-page book with basic skills such as recognition, cut, color, mesh, merge and complete. According to Mohd Sharani Ahmad (2006) the basic skills that these students need to master are also aimed at enabling them to compete with current needs, and through interviews also show that students are happy to produce story books. Observations and interviews with teachers can answer the research questions. How hands-on training exercises recognize, cut, grasp, combine and complement can help improve students' fine motor skills early in their education. Interview results with special education students with learning problems:

The first statement of a special education student with learning problems -Student 1:

I can make a four-page storybook and I know how to choose cartoons on the fabric I like. Not tired.

The second statement of a special education student with learning problems -Student 2:

I love to do four-page story books, I have my storybook ready and save it for my friends.

The third statement of a special education student with learning problems -Student 1:

I was able to attach all the pictures of the fabric with my friends and want to show them to my mom.

The third statement of a special education student with learning problems -Student 2:

I love making fabric story books.

The fourth statement of a special education student with learning problems -Student 1:

I can make a storybook using cartoon fabric and I really like using cartoons.

The fifth statement of a special education student with learning problems -Student 2 :

I was able to make a storybook out of fabric and I wanted to play with my friends, and I wasn't tired or sleepy.

\section{CONCLUSION}

Syamsulaini Sidek \& Mashitoh Hashim (2016). Teachers are leaders who guide students and allocate more time for learning activities, either individually or individually (Li, Mai \& Tse-Kian, 2014). It has been proven that fine motor activity activities can stimulate active learning and practice well but use a variety of end results such as four-page story books, puppets, puzzles and feather markers. 


\section{REFERENCES}

Shahabuddin Hashim \& Rohizani Yaakub (2003). Psikologi pembelajaran dan personaliti. Bentong: PTS Publications \& Distributors Sdn.Bhd. Winkel, W. S., \& Hastuti, M. S. (2005). Bimbingan dan Konseling di Institusi Pendidikan. Media Abadi.

Abd Khalil Adnan. (2017). Reka bentuk model program perkembangan profesionalisme guru Malaysia: Kuala Lumpur: Universiti Malaya .

Kauffman, J.M. \& Hallahan, D. P. (2005). Special Education: What It Is And Why We Need It. 2nd edition. Boston ; Montreal : Pearson/ Allyn and Bacon.

Li, Y.W., Mai, N., \& Tse-Kian, N. (2014). Impact of learner-centred teaching environment with the use of multimedia-mediated learning modules in improving learning experience. Jurnal Teknologi. 68(2), pp. 65-71.

Meyers, C. \& Jones, T.B. (1993). Promoting active learning. Strategies for the college classroom. San Francisco: Jossey-Bass Inc. Publishers.

Mohd.Sharani Ahmad, (2006). Mengurus kanak-kanak yang susah belajar. Seberang Prai Tengah: PTS.

Peter, C.J., Emeliana, E. \& Mohd Sofi, N. (2010). Perkembangan Kurikulum Pendidikan Khas Teknik dan Vokasional. Dicapai pada September 14, 2012, dari ms.1 di kurikulum_Pendidikan_Khas_Teknik_dan_Vok asional.pdf.

Syamsulaini Sidek \& Mashitoh Hashim (2016). VideoBased Teaching in Student-Centered Learning: Analysis and Critical Review: Journal of ICT in Education (JICTIE) ISSN 2289-7844 / Vol. 3 / 2016 / 24-33.

Silberman, M. (2000). Pembelajaran Aktif : 101 Strategik untuk Mengajar Apa Jua Pelajar. (Ahmad, Z. Trans.). Kuala Lumpur. Institut Penterjemahan Malaysia. 2004.

Zalizan Mohd Jelas. (Pnyt.). 2009. Pendidikan KanakKanak Bekeperluan Khas: Konsep dan Amalan. Bangi: Fakulti Pendidikan, Universiti kebangsaan Malaysia. 